\title{
Memory Improvement Effect of Ethanol Garlic (A. sativum) Extract in Streptozotocin-Nicotinamide Induced Diabetic Wistar Rats Is Mediated through Increasing of Hippocampal Sodium-Potassium ATPase, Glutamine Synthetase, and Calcium ATPase Activities
}

\author{
Ibrahim Semuyaba, Abass Alao Safiriyu, \\ Emmanuel Ayikobua Tiyo, and Remón Figueredo Niurka \\ Department of Physiology, Faculty of Biomedical Sciences, Kampala International University, Western Campus, Bushenyi, Uganda \\ Correspondence should be addressed to Ibrahim Semuyaba; ibrahim.semuyaba@kiu.ac.ug
}

Received 4 September 2017; Revised 7 November 2017; Accepted 12 December 2017; Published 27 December 2017

Academic Editor: Kuttulebbai N. S. Sirajudeen

Copyright (C) 2017 Ibrahim Semuyaba et al. This is an open access article distributed under the Creative Commons Attribution License, which permits unrestricted use, distribution, and reproduction in any medium, provided the original work is properly cited.

Studies suggest that garlic (A. sativum) improves memory dependent on the hippocampus. However, the effect of ethanol garlic extract on hippocampus $\mathrm{Na}^{+} / \mathrm{K}^{+}$ATPase, $\mathrm{Ca}^{2+}$ ATPase, and glutamine synthetase (GS) activities as possible mechanisms in memory improvement in diabetic Wistar rats has not been reported. Twenty-four male Wistar rats weighing 200-250 g were divided into three groups with 8 rats each. Group (A), normal control rats, and Group (B), diabetic rats, received 1 ml of normal saline; diabetic rats in Group (C) received $1000 \mathrm{mg} / \mathrm{kg}$ of garlic extract orally for 21 days. Hyperglycemia was induced by a single intraperitoneal injection of streptozotocin $60 \mathrm{mg} / \mathrm{kg}$ followed by $120 \mathrm{mg} / \mathrm{kg}$ nicotinamide while extraction of garlic was done by cold maceration method. Memory was tested in all groups. After that, the rats were sacrificed, the brain was removed, and the hippocampi were carefully excised and then homogenized. Activities of $\mathrm{Na}^{+} / \mathrm{K}^{+}$ATPase, calcium ATPase, and GS were analyzed from the homogenate. Results showed improvement in memory and a significant increase $(P<0.05)$ in hippocampus $\mathrm{Na}^{+} / \mathrm{K}^{+} \mathrm{ATPase} \mathrm{Ca}^{2+}$ ATPase, and GS activities in diabetic rats treated with garlic extract. In conclusion, the increased activity of hippocampus $\mathrm{Na}^{+} / \mathrm{K}^{+}$ ATPase, calcium ATPase, and glutamine synthetase may account for the memory improvement.

\section{Introduction}

Diabetes mellitus is a metabolic disease which leads to serious neuronal damage and cognitive deficits. It is considered as one of the causes of progressive neurodegeneration, with impairment in memory as a major complication [1]. This is shown by impairment in decision making and judgment especially in patients with this condition [2]. Elevated blood glucose levels in diabetic rats have been shown to impair memory by causing enhanced production of free radicals [3]. Studies have reported the alteration in transmembrane fluidity, affecting the activity of membrane receptors and inhibiting $\mathrm{Na}^{+} / \mathrm{K}^{+}$ATPase, $\mathrm{Ca}^{2+}$ ATPase [4], and glutamine synthetase [5].
Membrane bound enzymes $\mathrm{Na}^{+} / \mathrm{K}^{+}$ATPase and calcium ATPase are important in neuronal excitability and neurotransmitter release. These enzymes maintain concentration gradients of $\mathrm{Na}^{+}, \mathrm{K}^{+}$, and $\mathrm{Ca}^{2+}$ across the cell membrane. Inhibition of these enzymes leads to impairment in learning and memory [6]. Abnormalities in intracellular calcium ion regulation leads to neuronal death and impairment in neurological function [7]. In diabetic rat whole brain, suppression of $\mathrm{Ca}^{2+}$ ATPase and $\mathrm{Na}^{+} / \mathrm{K}^{+}$ATPase activities has been reported [8]. Glutamine synthetase is an enzyme important in controlling intracellular concentration of glutamate. It is suggested that accumulation of glutamate in the extracellular fluid causes a decrease in glutamine synthetase which may lead to seizures [9]. It has been reported that when there is 
inhibition of glutamine synthetase, neurotransmission at the synapse in the retina is affected [10].

Herbs as an alternative treatment of DM especially in poor countries have been utilized more frequently in treating patients with diabetes. World Health Organization indicated that more than $80 \%$ of the people in the world trust use of herbal medicines $[11,12]$ and in developing countries 3.5 billion are estimated to use medicinal plants [13]. Garlic as one of the herbs has been shown to have numerous medicinal properties. It has been suggested to have antiangiogenic effects [14] and prevent apoptosis and toxicity to neurons by A-beta [15]. Garlic has been shown to improve learning and memory in rats fed with fructose [16]. Aged garlic extracts reduce impairment in cognition in rats induced with $\mathrm{A} \beta$ [17]. Different preparations of garlic extract improve short term memory in diabetic rats [18]. According to reviewed literature, the effect of ethanol garlic (A. sativum) extract on the activities of hippocampus $\mathrm{Ca}^{2+}$ ATPase, $\mathrm{Na}^{+} / \mathrm{K}^{+}$ATPase, glutamine synthetase and it link with memory in diabetic rats has not been studied. However, we have reported that hippocampus $\mathrm{Na}^{+} / \mathrm{K}^{+}$ATPase and $\mathrm{Ca}^{2+}$ ATPase are involved in spatial working memory in normal Wistar rats [19]. We further explored the possibility of memory improvement in STZ-nicotinamide induced diabetic Wistar rats by studying the effect of ethanol garlic (A. sativum) extract on the activities of hippocampus $\mathrm{Na}^{+} / \mathrm{K}^{+}$ATPase, glutamine synthetase, and $\mathrm{Ca}^{2+}$ ATPase.

\section{Materials and Methods}

2.1. Ethanol Garlic Extraction. The cold maceration method as described in [20] was used. Extraction was carried out at the biomedical research laboratory in Western Campus, KIU (Kampala International University), Uganda. Pieces of small garlic which weighed $500 \mathrm{~g}$ were peeled and later homogenized in cold $0.9 \% \mathrm{NaCl}$ sterile solution in a volume of $70 \mathrm{ml}$. The resultant paste was then suspended for 48 hours in $80 \%$ ethanol in an air tight jar and shaken after every five minutes, 3 times a day. After 48 hours, suspension was filtrated using filter paper of Whitman type. After three times of repeated filtration, a clear filtrate was obtained. A rotary evaporator was then used to concentrate the filtrate at $40^{\circ} \mathrm{C}$ in a water bath. The concentrated extract was placed in a conical flask and evaporated further at $50^{\circ} \mathrm{C}$ in an oven, after which the extract of the study was obtained.

2.2. Experimental Rats. Twenty-four (24) male Wistar rats weighing 200-250 g were used. These were purchased from animal facility at MUST (Mbarara University of Science and Technology). The rats were housed in clean cages in the animal house facility at KIU Western campus which were used to house the experimental rats and then they were acclimatized to new surroundings for two weeks. Standard rat pellets were purchased from Nuvita Feeds (U) Ltd and water was provided throughout the experimental period with exception when fasting blood glucose levels were taken [21]. The experimental rats were divided randomly into three groups each having 8 rats (Table 1 ).
TABLE 1

\begin{tabular}{ll}
\hline Groups & Treatments \\
\hline $\begin{array}{l}\text { (A) Normal control } \\
\text { rats }\end{array}$ & $\begin{array}{l}\text { Normal rats orally given } 1 \mathrm{ml} \text { of normal } \\
\text { saline daily. }\end{array}$ \\
\hline (B) Diabetic rats & $\begin{array}{l}\text { Hyperglycemic rats fed with standard } \\
\text { pellet diet and orally given } 1 \mathrm{ml} \text { of normal } \\
\text { saline. }\end{array}$ \\
\hline (C) Diabetic rats + & $\begin{array}{l}1000 \mathrm{mg} / \mathrm{kg} \text { of ethanol extract of garlic } \\
\text { administered to hyperglycemic rats daily } \\
\text { for three weeks. }\end{array}$ \\
\hline
\end{tabular}

2.3. Induction of Hyperglycemia in Wistar Rats. Wistar rats were allowed to feed freely for five days. Sixty (60) $\mathrm{mg} / \mathrm{kg}$ streptozotocin purchased from Sigma Aldrich was dissolved in $0.05 \mathrm{ml}$ of citrate buffer $(\mathrm{pH} 4.5)$ and $120 \mathrm{mg} / \mathrm{kg}$ nicotinamide purchased from Zac's pharmacy in Bushenyi was dissolved in $0.5 \mathrm{ml}$ of normal saline. Hyperglycemia was induced using a single intraperitoneal injection of $60 \mathrm{mg} / \mathrm{kg} \mathrm{STZ}$ and after 15 minutes $120 \mathrm{mg} / \mathrm{kg}$ nicotinamide was injected intraperitoneally [22]. Elevated levels of blood glucose were confirmed 3 days after induction by collecting blood samples from the rat tail vein through a small cut. Blood glucose levels were measured using one call glucometer [23]. Rats confirmed being hyperglycemic with blood glucose concentration ( $\geq 250 \mathrm{mg} / \mathrm{dl})$ used for the study [22].

2.4. Hippocampus Dependent Memory Assessment. The method described [24] with minor modifications was used to assess memory. The experimental apparatus consisted of a box made out of plywood and measured $40 \mathrm{~cm} \times$ $640 \mathrm{~cm} \times 630 \mathrm{~cm}$. Saw dust was spread two inches on the floor and lighting using overhead bulb was used. The objects and arena were cleaned using $70 \%$ ethanol on each day of the experiment and reducing olfactory cues fresh bedding was provided for each day. Object location memory test was carried out for 3 days. This test was performed, before induction of hyperglycemia and then 21 days after confirmation of hyperglycemia. The experiment was carried out for three days. On day one (habituation), the rats explored the box and behavioural room for 5-minute exposures two times and no objects were placed in the arena during this day. The cage was cleaned to remove any feces and the rat was then returned after exploration. Habituation proceeded to another rat and repeated following the same arrangement after all rats had been habituated. On training day (second day), two objects which were identical measuring $1.2 \times 2500$ inches were placed in the box 2.5 centimetres from its wall. The objects were located in corners A and B, $2.5 \mathrm{~cm}$ apart. Rats explored the two objects freely for a 10-minute trial. Those rats which failed to explore the objects on day one for less than ten seconds were not included for analysis. Memory testing occurred on day 3. To test memory, object exploration time in novel versus familiar locations was done. For each trial, one of the objects was placed in the centre of the arena instead of its original location. The experiment was run similarly during training, with 10-minute trials. All trials were videotaped with VDO camcorder version-052, USA, 
TABLE 2

\begin{tabular}{|c|c|c|c|c|}
\hline \multicolumn{5}{|c|}{ Fasting blood glucose levels (mg/dl) } \\
\hline Groups & Day 3 & Day 7 & Day 14 & Day 21 \\
\hline (A) Normal control rats & $110 \pm 0.64$ & $108 \pm 0.58$ & $109 \pm 0.39$ & $108 \pm 0.38$ \\
\hline (B) Diabetic rats & $323 \pm 19.34$ & $344 \pm 12.42$ & $449 \pm 7.41$ & $468 \pm 6.07$ \\
\hline (C) Diabetic rats $+1000 \mathrm{mg} / \mathrm{kg}$ of ethanol garlic extract & $330 \pm 14.63$ & $297 \pm 21.36$ & $143 \pm 0.99$ & $137 \pm 0.41^{*}$ \\
\hline
\end{tabular}

Results are expressed as mean $\pm \operatorname{SEM}(n=8)$. The data was analyzed using ANOVA followed by Tukey's post hoc test. ${ }^{*} P<0.001$ versus diabetic rats.

and analyzed later by trained technician. The exploration time in seconds of objects in novel and familiar locations was recorded for each rat and later analyzed. Exploration time was scored when the rat's head or nose touched the objects. Standing, sitting, and sniffing on the objects were also scored. Novelty index in percentage was calculated as follows.

Time spent exploring object in novel location is divided by the total time spent exploring both objects in novel and familiar locations and then multiplied by $100 \%$.

2.5. Collection of Hippocampus Samples and Processing. After the memory test, the rats were placed in a container with a lid containing a towel dipped in 99\% diethyl ether for 2 minutes. The rats were then sacrificed, the brain was removed, and the hippocampi were excised carefully and then homogenized to obtain a homogenate which was then centrifuged to obtain a supernatant used in analysis for $\mathrm{GS}, \mathrm{Na}^{+} / \mathrm{K}^{+}$ATPase, and $\mathrm{Ca}^{2+}$ ATPase activities.

2.6. Determining $\mathrm{Na}^{+} / \mathrm{K}^{+}$ATPase Activity. The method described [25] was used to analyze thirty (30) hippocampal homogenates for $\mathrm{Na}^{+} / \mathrm{K}^{+}$ATPase activity. Assay mixture $(\mathrm{mM})$ consisted of $50 \mathrm{NaCl}, 30$ Tris-HCl buffer ( $\mathrm{pH} 7.4$ ), $6 \mathrm{MgCl}_{2}, 0.1 \mathrm{EDTA}, 5 \mathrm{KCl}$, and a protein concentration of $50 \mu \mathrm{g}$. Ouabain $(1 \mathrm{mM})$ was added making a concentration of $350 \mu \mathrm{L}$. Adenosine triphosphate (ATP) was added to start the reaction to form a $3 \mathrm{mM}$ concentration. The reaction was stopped 30 minutes when $50 \%$ trichloroacetic acid in a volume of $70 \mu \mathrm{L}$ was added at a temperature of $37^{\circ} \mathrm{C}$. The amount Pi liberated was calorimetrically quantified according to method described [26], using a standard reference of $300 \mathrm{KH}_{2} \mathrm{PO}_{4}$. The activity of $\mathrm{Na}^{+} / \mathrm{K}^{+}$ATPase in $\mathrm{Pi} / \mathrm{min} / \mathrm{mg}$ of protein in nmol was determined in the absence of ouabain from the overall activity.

2.7. Determining $\mathrm{Ca}^{2+}$ ATPase Activity. The activity of $\mathrm{Ca}^{2+}$ ATPase in 30 hippocampal homogenates was determined according to the method described [27]. The method [26] was used to estimate $\mathrm{Pi}$ (inorganic phosphates). $3 \mathrm{MgCl}_{2}, 30$ Tris-HCl buffer (pH 7.4), 0.1 EGTA all in $\mathrm{mM}$, and $100 \mu \mathrm{g}$ of protein in the presence or absence of $0.4 \mathrm{CaCl}_{2}$ in a $200 \mu \mathrm{L}$ volume formed the medium of the assay. Addition of ATP started the reaction to give $3 \mathrm{mM}$ as the final volume. Fifty percent addition of trichloroacetic acid in a volume of $70 \mu \mathrm{L}$ after 60 minutes and at thirty-seven degrees Celsius stopped the reaction. The reaction was linear with concentration of protein and time. The assay consisted of control solutions, which were used in nonenzymatic adenosine triphosphate hydrolysis. The liberated Pi was calculated calorimetrically with a reference solution of $\mathrm{KH}_{2} \mathrm{PO}_{4} \cdot \mathrm{Ca}^{2+}$ ATPase activity was calculated in $\mathrm{Pi} / \mathrm{min} / \mathrm{mg}$ protein in nmol by subtracting the measured activity from calcium ions absence.

2.8. Determining Glutamine Synthetase Activity. The method [28] was used in the enzymatic assay of glutamine synthetase. In this method, $0.1 \mathrm{~mL}$ homogenates solubilised in $140 \mathrm{mM}$ $\mathrm{KCl}$ were added to $0.1 \mathrm{~mL}$ of the reaction mixture in $\mathrm{mM}$ and incubated for $15 \mathrm{~min}\left(37^{\circ} \mathrm{C}\right)$. The reaction was stopped by $0.4 \mathrm{~mL}$ addition of a solution containing (in $\mathrm{mM}$ ) 370 ferric chloride, $200 \mathrm{TCA}$, and $670 \mathrm{HCl}$. The absorbance of the supernatant was measured at $720 \mathrm{~nm}$ after centrifugation and standard quantities of ferric chloride reagent treated with cglutamyl hydroxamate were compared to the absorbance generated. Results were expressed as percentages of the control condition in $\mathrm{mMol}$ of gamma glutamyl hydroxamate $/ \mathrm{hr} / \mathrm{mg}$ protein.

2.9. Statistical Analysis. Results were expressed as mean \pm SEM and analyzed statistically using ANOVA followed by Tukey's multiple comparison post hoc test with $P<0.05$ considered significant.

\section{Results}

3.1. The Effect of Ethanol Garlic (A. sativum) Extract on Blood Glucose Levels. The blood glucose levels for each week in diabetic rats were higher as compared to normal control rats. There was a significant decrease in blood glucose levels of diabetic rats treated with garlic (A. sativum) extract as compared with diabetic control rats (Table 2). Fasting blood glucose levels are expressed as $\mathrm{mg} / \mathrm{dl}$.

3.2. Effect of Ethanol Garlic Extract on Novelty Index in Different Groups. The novelty index was calculated as a percentage. The novelty index in the diabetic rats which received normal saline $(49 \pm 0.22)$ was significantly reduced $(P<0.05)$ compared with that of normal control rats $(55 \pm$ 0.11 ) (Table 3). However, when the diabetic rats were treated with garlic (A. sativum), there was significant increase $(P>$ $0.05)$ in the novelty index $(61.4 \pm 0.20)$ compared to the novelty index $(49 \pm 0.22)$ of the diabetic rats (Table 3 ).

\subsection{Effect of Ethanol Garlic (A. sativum) Extract on Activity} of Hippocampus $\mathrm{Na}^{+} / \mathrm{K}^{+}$ATPase. Data of hippocampus sodium-potassium ATPase activity was measured as $\mu \mathrm{mol}$ of Pi liberated $/ \mathrm{min} / \mathrm{mg}$ protein. In diabetic controls, $\mathrm{Na}^{+} / \mathrm{K}^{+}$ ATPase activity $(0.338 \pm 0.02)$ was significantly decreased 
TABLE 3: Showing the effect of ethanol garlic extract on the novelty index in different groups.

\begin{tabular}{lc}
\hline Groups & Novelty index (percentage) \\
\hline (A) Normal control rats & $55 \pm 0.11$ \\
(B) Diabetic rats & $49 \pm 0.22$ \\
(C) Diabetic rats + garlic at $1000 \mathrm{mg} / \mathrm{kg}$ b.w. & $61.4 \pm 0.20^{*}$ \\
\hline
\end{tabular}

Results are expressed as mean $\pm \operatorname{SEM}(n=8) .{ }^{*} P<0.05$ versus diabetic rats.

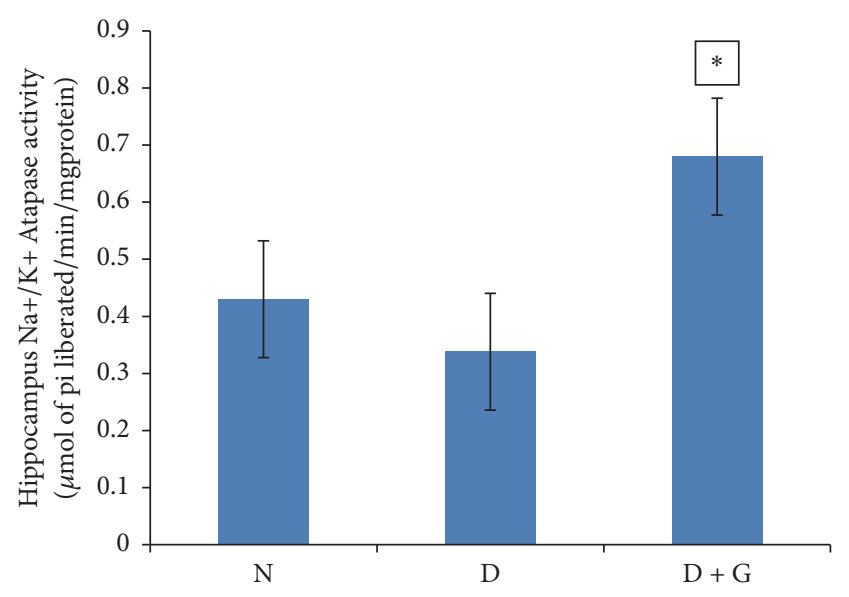

Figure 1: Showing effect of ethanol garlic (A. sativum) extract on activity of hippocampus $\mathrm{Na}^{+} / \mathrm{K}^{+}$ATPase in the different groups. Each bar represents a mean of eight samples. ${ }^{*} P<0.05$ versus diabetic control group. $\mathrm{N}=$ normal + saline; $\mathrm{D}=$ diabetic rats + saline; $\mathrm{D}+\mathrm{G}=$ diabetic rats that received $1000 \mathrm{mg} / \mathrm{kg}$ of garlic $(A$. sativum) extract.

$(P>0.05)$ when compared with normal control rats that received normal saline $(0.43 \pm 0.01)$ (Figure 1$)$. Administration of garlic (A. sativum) to diabetic rats at a dose of $1000 \mathrm{mg} / \mathrm{kg}$ resulted in a significant increase $(P<0.05)$ in hippocampus $\mathrm{Na}^{+} / \mathrm{K}^{+}$ATPase activity $(0.68 \pm 0.01)$ compared to diabetic control rats $(0.338 \pm 0.02)$ (Figure 1$)$.

3.4. Effect of Ethanol Garlic (A. sativum) Extract on Hippocampus Calcium ATPase Activity. Activity of hippocampus $\mathrm{Ca}^{2+}$ ATPase was calculated as $\mu \mathrm{mol}$ of Pi liberated $/ \mathrm{min} / \mathrm{mg}$ protein.

Hippocampus $\mathrm{Ca}^{2+}$ ATPase activity in diabetic control rats $(0.438 \pm 0.019)$ decreased significantly $(P>0.05)$ as compared with normal control rats $(0.56 \pm 0.18)$ (Figure 2). Following treatment of ethanol garlic (A. sativum) extract to diabetic rats at a dose of $1000 \mathrm{mg} / \mathrm{kg}$, hippocampus $\mathrm{Ca}^{2+}$ ATPase activity $(1.22 \pm 0.037)$ had a significant increase $(P<0.05)$ in comparison to diabetic controls $(0.438 \pm 0.019)$ (Figure 2).

3.5. Effect of Ethanol Garlic (A. sativum) Extract on Hippocampus Glutamine Synthetase Activity. Hippocampus glutamine synthetase activity was expressed as $\mathrm{mMol}$ of gamma glutamyl hydroxamate/hr/mg protein. Results showed that diabetic control rats recorded a significantly decreased $(P>$ $0.05)$ hippocampus glutamine synthetase activity $(0.32 \pm$ $0.001)$ when compared to normal control rats $(0.478 \pm 0.01)$

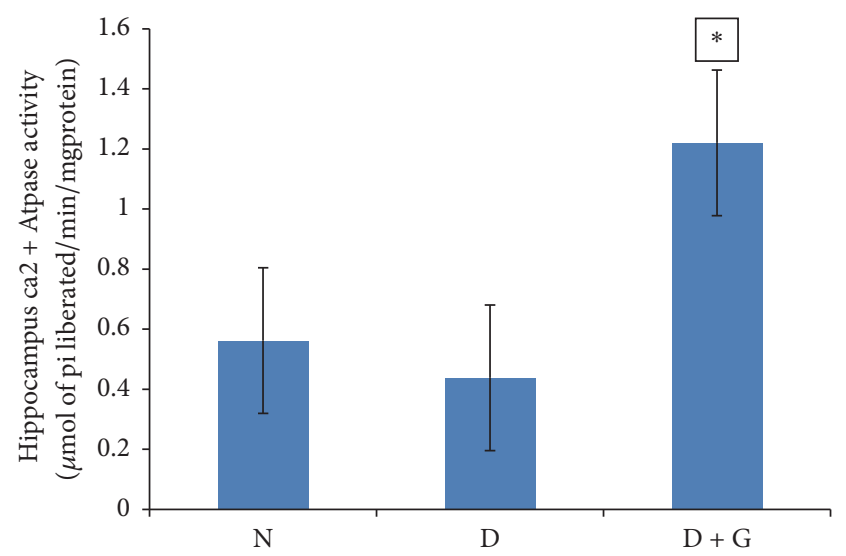

FIGURE 2: Showing the effect of ethanol garlic (A. sativum) extract on hippocampus calcium ATPase activity in different groups. Each bar represents a mean of eight samples. ${ }^{*} P<0.05$ versus diabetic control group. $\mathrm{N}=$ normal + saline; $\mathrm{D}=$ diabetic rats + saline; $\mathrm{D}$ $+\mathrm{G}=$ diabetic rats that received $1000 \mathrm{mg} / \mathrm{kg}$ of garlic (A. sativum) extract.

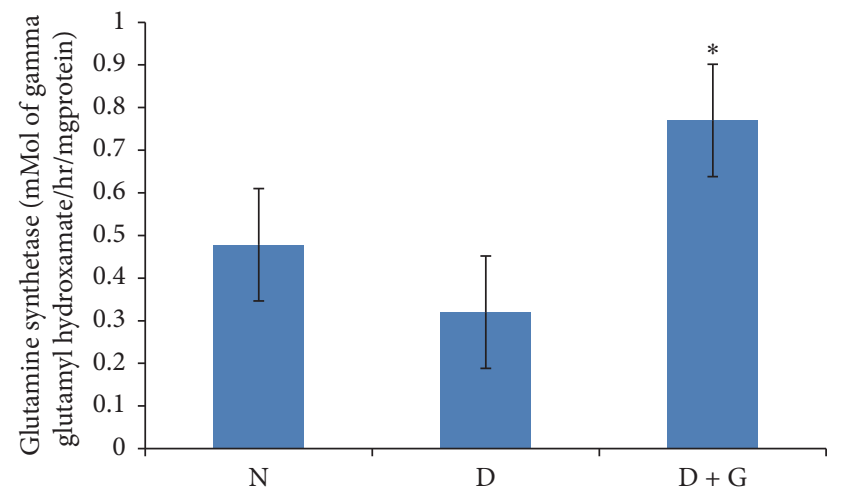

FIGURE 3: Showing effect of ethanol garlic (A. sativum) extract on hippocampus glutamine synthetase activity in different groups. Each bar represents a mean of eight samples. ${ }^{*} P<0.05$ versus diabetic control group. $\mathrm{N}=$ normal + saline; $\mathrm{D}=$ diabetic rats + saline; $\mathrm{D}$ $+\mathrm{G}=$ diabetic rats that received $1000 \mathrm{mg} / \mathrm{kg}$ of garlic (A. sativum) extract.

(Figure 3). Treatment of diabetic rats with ethanol garlic (A. sativum) extract increased significantly $(P<0.05)$ hippocampus glutamine synthetase activity $(0.77 \pm 0.003)$ compared to diabetic control rats $(0.32 \pm 0.001)$ (Figure 3$)$.

\section{Discussion}

The purpose of the current study was to determine the effect of ethanol garlic (A. sativum) extract on activities of 
hippocampus $\mathrm{Na}^{+} / \mathrm{K}^{+}$ATPase, glutamine synthetase, and $\mathrm{Ca}^{2+}$ ATPase in streptozotocin-nicotinamide induced in diabetic Wistar rats as possible mechanisms for memory improvement. Results showed that the preference for novelty was significantly reduced in the diabetic rats, indicating impairment in memory. This result is consistent with studies [18, 29-31]. However, when the diabetic Wistar rats were treated with garlic (A. sativum) extract, there was an increased preference for novelty suggesting an improvement in memory. This result is in agreement with previous studies $[18,32] . \mathrm{Na}^{+} / \mathrm{K}^{+}$ATPase is important in regulating cell volume, active transport of $\mathrm{K}^{+}$into the cell with outflow of $\mathrm{Na}^{+}$, transmembrane fluxes of $\mathrm{Ca}^{2+}$, and neurotransmitters release [33]. Results showed a significantly decreased activity of hippocampus $\mathrm{Na}^{+} / \mathrm{K}^{+}$ATPase in rats with diabetes. This is consistent with previously reported studies where $\mathrm{Na}^{+} / \mathrm{K}^{+}$ ATPase activity decreased in brain of diabetic rats [31, 34]. The decreased activity of $\mathrm{Na}^{+} / \mathrm{K}^{+}$ATPase could be related to increased oxidative stress in the hippocampus [35]. This leads to death of neurons due to a reduction in antioxidant defence mechanisms [36]. Administration of garlic has been shown to reduce production of reactive oxygen species [37]. In this study, treatment of diabetic rats with garlic extract increased significantly the activity of hippocampus $\mathrm{Na}^{+} / \mathrm{K}^{+}$ ATPase suggesting the ability of garlic to enhance functioning of this enzyme. $\mathrm{Ca}^{2+}$ ATPases are crucial for maintenance of intracellular calcium levels. Results showed that $\mathrm{Ca}^{2+}$ ATPase activity was significantly decreased in the hippocampus of diabetic rats. This is in line with studies [31,34]. This could be due to increase in formation of lipid peroxides [38] or overload of intracellular calcium levels [39]. It has been suggested that increase in intracellular $\mathrm{Ca}^{2+}$ concentration occurs due to $\mathrm{Ca}^{2+}$ ATPase inhibition and leads to alteration in signalling pathways [40]. It has been reported that the activity of this enzyme is related to the surrounding structural and lipid environment of the synaptosomal membrane [41]. Indeed, the decrease in activity of $\mathrm{Ca}^{2+}$ ATPase may be due to alterations in membrane phospholipids, which is related closely to the microenvironment around the enzyme [42]. It has been suggested that S-allyl cysteine, Alliin, compounds in garlic prevent degradation of membrane lipids [43]. The significant increase in activity of hippocampus calcium ATPase after treatment of diabetic rats with garlic extract may suggest the effect of active compounds in garlic in restoration of $\mathrm{Ca}^{2+}$ ATPase activity. Neurotransmitter glutamate is released from glutamatergic neuronal vesicles through a calciumdependent mechanism. Glutamine synthetase (GS) is an enzyme important in controlling the intracellular concentration of glutamate by converting it into glutamine [44]. Glutamine synthetase helps to maintain the concentration of ammonia within normal limits because excessive amounts of ammonia ions are toxic to the brain [45]. The decreased activity could be due to downregulation of the enzyme, increased clearance of glutamine synthetase, and modulation of its activity by nitric oxide [46]. GS is suggested to be vulnerable to increased protein oxidation and nitration which inhibits its activity [5,47]. Treatment with garlic extract increased significantly the activity of hippocampus glutamine synthetase suggesting activation of this enzyme.

In conclusion, based on the results of the present study showing that ethanol garlic (A. sativum) extract improves memory in STZ-nicotinamide induced diabetic Wistar rats, the mechanism for this improvement could be due to increase in activities of hippocampus sodium-potassium ATPase, $\mathrm{Ca}^{2+}$ ATPase, and glutamine synthetase.

\section{Conflicts of Interest}

The authors declare that there are no conflicts of interest.

\section{Acknowledgments}

Special thanks are due to Kampala International University for providing financial support.

\section{References}

[1] H. Sacai, S. Sasaki-Hamada, A. Sugiyama et al., "The impairment in spatial learning and hippocampal LTD induced through the PKA pathway in juvenile-onset diabetes rats are rescued by modulating NMDA receptor function," Neuroscience Research, vol. 81-82, pp. 55-63, 2014.

[2] K. G. Yiannopoulou and S. G. Papageorgiou, "Current and future treatments for Alzheimer's disease," Therapeutic Advances in Neurological Disorders, vol. 6, no. 1, pp. 19-33, 2013.

[3] J. Pearson-Leary and E. C. McNay, "Intrahippocampal administration of amyloid- $\beta 1-42$ oligomers acutely impairs spatial working memory, insulin signaling, and hippocampal metabolism," Journal of Alzheimer's Disease, vol. 30, no. 2, pp. 413-422, 2012.

[4] L. F. Dmitriev and V. N. Titov, "Lipid peroxidation in relation to ageing and the role of endogenous aldehydes in diabetes and other age-related diseases," Ageing Research Reviews, vol. 9, no. 2, pp. 200-210, 2010.

[5] B. Görg, H. J. Bidmon, V. Keitel et al., "Inflammatory cytokines induce protein tyrosine nitration in rat astrocytes," Archives of Biochemistry and Biophysics, vol. 449, no. 1-2, pp. 104-114, 2006.

[6] S. J. Clapcote, S. Duffy, G. Xie et al., "Mutation I810N in the $\alpha 3$ isoform of $\mathrm{Na}+\mathrm{K}+$-ATPase causes impairments in the sodium pump and hyperexcitability in the CNS," Proceedings of the National Acadamy of Sciences of the United States of America, vol. 106, no. 33, pp. 14085-14090, 2009.

[7] N. C. Spitzer, C. M. Root, and L. N. Borodinsky, "Orchestrating neuronal differentiation: Patterns of $\mathrm{Ca} 2+$ spikes specify transmitter choice," Trends in Neurosciences, vol. 27, no. 7, pp. 415421, 2004.

[8] P. Kumar, R. K. Kale, P. McLean, and N. Z. Baquer, "Antidiabetic and neuroprotective effects of Trigonella foenum-graecum seed powder in diabetic rat brain.," Prague Medical Report, vol. 113, no. 1, pp. 33-43, 2012.

[9] E. L. Perez, F. Lauritzen, Y. Wang et al., "Evidence for astrocytes as a potential source of the glutamate excess in temporal lobe epilepsy," Neurobiology of Disease, vol. 47, no. 3, pp. 331-337, 2012.

[10] B. V. Bui, R. G. Hu, M. L. Acosta, P. Donaldson, A. J. Vingrys, and M. Kalloniatis, "Glutamate metabolic pathways and retinal function," Journal of Neurochemistry, vol. 111, no. 2, pp. 589-599, 2009. 
[11] V. Duraipandiyan, M. Ayyanar, and S. Ignacimuthu, "Antimicrobial activity of some ethnomedicinal plants used by Paliyar tribe from Tamil Nadu, India," BMC Complementary and Alternative Medicine, vol. 6, article 35, 2006.

[12] R. J. McCrimmon, C. M. Ryan, and B. M. Frier, "Diabetes and cognitive dysfunction," The Lancet, vol. 379, no. 9833, pp. 22912299, 2012.

[13] D. T. Jamison, J. G. Breman, A. R. Measham et al., Disease Control Priorities in Developing Countries, World Bank Group/E Libr, 2nd edition, 2006.

[14] A. Herman-Antosiewicz, A. A. Powolny, and S. V. Singh, "Molecular targets of cancer chemoprevention by garlic-derived organosulfides," Acta Pharmacologica Sinica, vol. 28, no. 9, pp. 1355-1364, 2007.

[15] C. Borek, "Antioxidant health effects of aged garlic extract," Journal of Nutrition, vol. 131, no. 3, pp. 1010S-1015S, 2001.

[16] R. Jalal, S. M. Bagheri, and A. Moghimi, “The effect of Iranian shallot or garlic aqueous extracts on learning, memory and serum biochemical variables in fructose-fed wistar rats," Iranian Journal of Basic Medical Sciences, vol. 14, no. 3, pp. 284-289, 2011.

[17] J. H. Jeong, H. R. Jeong, Y. N. Jo, H. J. Kim, J. H. Shin, and H. J. Heo, "Ameliorating effects of aged garlic extracts against $\mathrm{A} \beta$-induced neurotoxicity and cognitive impairment," $B M C$ Complementary and Alternative Medicine, vol. 13, article no. 268, 2013.

[18] A. Sarkaki, S. V. Chehardacheric, Y. Farbood, S. M. T. Mansouri, B. Naghizadeh, and E. Basirian, "Effects of fresh, aged and cooked garlic extracts on short- and long-term memory in diabetic rats," Avicenna Journal of phytomedicine, vol. 3, no. 1, pp. 45-55, 2013.

[19] S. A. Alao, S. Ibrahim, R. F. Niurka, and E. T. Akhigb, "Garlic Extract (Allium sativum) Enhances Spatial Working Memory in Wistar Rats: Involvement of Hippocampal $\mathrm{Na}+/ \mathrm{K}+$ ATPase and Ca2+ ATPase Activities," Journal of Behavioral and Brain Science, vol. 7, pp. 31-40, 2017.

[20] T. Baluchnejadmojarad, M. Roghani, H. Homayounfar, and M. Hosseini, "Beneficial effect of aqueous garlic extract on the vascular reactivity of streptozotocin-diabetic rats," Journal of Ethnopharmacology, vol. 85, no. 1, pp. 139-144, 2003.

[21] J. C. Ozougwu, K. C. Obimba, C. D. Belonwu, and C. B. Unakalamba, "The pathogenesis and pathophysiology of type 1 and type 2 diabetes mellitus," Journal of Physiology and Pathophysiology, vol. 4, no. 4, pp. 46-57, 2013.

[22] M. A. Satheesh and L. Pari, "Effect of pterostilbene on lipids and lipid profiles in streptozotocin-nicotinamide induced type 2 diabetes mellitus," Journal of Applied Biomedicine, vol. 6, no. 1, pp. 31-37, 2007.

[23] P. M. Thulé, A. G. Campbell, D. J. Kleinhenz et al., "Hepatic insulin gene therapy prevents deterioration of vascular function and improves adipocytokine profile in STZ-diabetic rats," American Journal of Physiology-Endocrinology and Metabolism, vol. 290, no. 1, pp. E114-E122, 2006.

[24] H. Gerstein, R. Hullinger, M. J. Lindstrom, and C. Burger, "A Behavioral Paradigm to Evaluate Hippocampal Performance in Aged Rodents for Pharmacological and Genetic Target Validation," PLoS ONE, vol. 8, no. 5, Article ID e62360, 2013.

[25] R. Tirri, K. Y. H. Lagerspetz, and J. Kohonen, “Temperature dependence of the ATP-ase activities in brain homogenates during the postnatal development of the rat," Comparative Biochemistry and Physiology, vol. 44, no. 2, pp. 473-480, 1973.
[26] C. H. Fiske and Y. Subbarow, "The colorimetric determination of phosphorous," The Journal of Biological Chemistry, vol. 66, pp. 375-400, 1925.

[27] D. Desaiah and I. K. Ho, "Effects of acute and continuous morphine administration on catecholamine-sensitive adenosine triphosphatase in mouse brain," The Journal of Pharmacology and Experimental Therapeutics, vol. 208, no. 1, pp. 80-85, 1979.

[28] W. Bruce Rowe, R. A. Ronzio, V. P. Wellner, and A. Meister, "Glutamine Synthetase (Sheep Brain)," Methods in Enzymology, vol. 17, pp. 900-910, 1970.

[29] K. Lee, Y. Chen, C. Lin, W. Chiu, H. Liao, and S. Lin, "Consumption of Oriental Plums Improved the Cognitive Performance and Modulated the Cerebral Neurodegeneration-Related Protein Expressions in Rats with Nicotinamide/StreptozotocinInduced Diabetes," Journal of Food and Nutrition Sciences, vol. 04, no. 11, pp. 1145-1154, 2013.

[30] W. Pierre, A. J. H. Gildas, M. C. Ulrich, W.-N. Modeste, N. T. Benoît, and K. Albert, "Hypoglycemic and hypolipidemic effects of Bersama engleriana leaves in nicotinamide/ streptozotocin-induced type 2 diabetic rats," BMC Complementary \& Alternative Medicine, vol. 12, article 264, 2012.

[31] N. Giribabu, N. Srinivasarao, S. Swapna Rekha, S. Muniandy, and N. Salleh, "Centella asiatica attenuates diabetes induced hippocampal changes in experimental diabetic rats," EvidenceBased Complementary and Alternative Medicine, vol. 2014, Article ID 592062, 2014.

[32] H. Nishimura, O. Higuchi, K. Tateshita, K. Tomobe, Y. Okuma, and Y. Nomura, "Antioxidative activity and ameliorative effects of memory impairment of sulfur-containing compounds in Allium species," BioFactors, vol. 26, no. 2, pp. 135-146, 2006.

[33] R. W. S. G. Albers, Membrane transport. Basic Neurochemistry: Principles of Molecular, Cellular and Medical Neurobiology, 8th edition, 2012.

[34] P. Kumar, R. K. Kale, and N. Z. Baquer, "Antihyperglycemic and protective effects of Trigonella foenum graecum seed powder on biochemical alterations in alloxan diabetic rats," European Review for Medical and Pharmacological Sciences, vol. 16, no. 3, pp. 18-27, 2012.

[35] B. H. Lee, C. C. Lee, and S. C. Wu, "Ice plant (Mesembryanthemum crystallinum) improves hyperglycaemia and memory impairments in a Wistar rat model of streptozotocin-induced diabetes," Journal of the Science of Food and Agriculture, vol. 94, no. 11, pp. 2266-2273, 2014.

[36] H. K. Moghaddam, T. Baluchnejadmojarad, and M. Roghani, "Berberine ameliorate oxidative stress and astrogliosis in the hippocampus of STZ-induced diabetic rats," Molecular Neurobiology, vol. 49, no. 2, pp. 820-826, 2014.

[37] M. M. Rahman, V. Fazlic, and N. W. Saad, "Antioxidant properties of raw garlic (Allium sativum) extract," International Food Research Journal, vol. 19, no. 2, pp. 589-591, 2012.

[38] N. Z. Baquer, A. Taha, P. Kumar et al., "A metabolic and functional overview of brain aging linked to neurological disorders," Biogerontology, vol. 10, no. 4, pp. 377-413, 2009.

[39] S. Doğru, P. B. Daş, and E. N. Nebioğlu, "Diabetes-induced decrease in rat brain microsomal Ca2+-ATPase activity," Cell Biochemistry and Function, vol. 23, no. 4, pp. 239-243, 2005.

[40] M. Aubier and N. Viires, "Calcium ATPase and respiratory muscle function," European Respiratory Journal, vol. 11, no. 3, pp. 758-766, 1998.

[41] C. Hidalgo, "Lipid-protein interactions and the function of the Ca2+-ATPase of sarcoplasmic reticulum.," CRC Critical Reviews in Biochemistry, vol. 21, no. 4, pp. 319-347, 1987. 
[42] Y. Kuwahara, T. Yanagishita, N. Konno, and T. Katagiri, "Changes in microsomal membrane phospholipids and fatty acids and in activities of membrane bound enzyme in diabetic rat heart," Basic Research in Cardiology, vol. 92, no. 4, pp. 214222, 1997.

[43] N. Ide, H. Matsuura, and Y. Itakura, "Scavenging effect of aged garlic extract and its constituents on active oxygen species," Phytotherapy Research, vol. 10, no. 4, pp. 340-341, 1996.

[44] F. Blandini, R. H. P. Porter, and J. T. Greenamyre, "Glutamate and Parkinson's disease," Molecular Neurobiology, vol. 12, no. 1, pp. 73-94, 1996.

[45] L. Hertz, R. Dringen, A. Schousboe, and S. R. Robinson, "Astrocytes: Glutamate producers for neurons," Journal of Neuroscience Research, vol. 57, no. 4, pp. 417-428, 1999.

[46] S. W. Barger, M. E. Goodwin, M. M. Porter, and M. L. Beggs, "Glutamate release from activated microglia requires the oxidative burst and lipid peroxidation," Journal of Neurochemistry, vol. 101, no. 5, pp. 1205-1213, 2007.

[47] M. Swamy, K. N. S. Sirajudeen, and G. Chandran, "Nitric oxide (NO), citrullineNO cycle enzymes, glutamine synthetase, and oxidative status in kainic acid-mediated excitotoxicity in rat brain," Drug and Chemical Toxicology, vol. 32, no. 4, pp. 326331, 2009. 


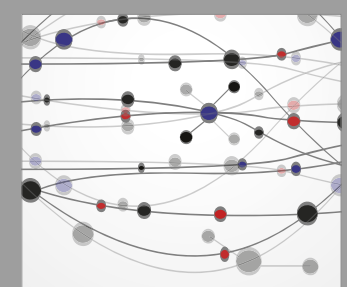

The Scientific World Journal
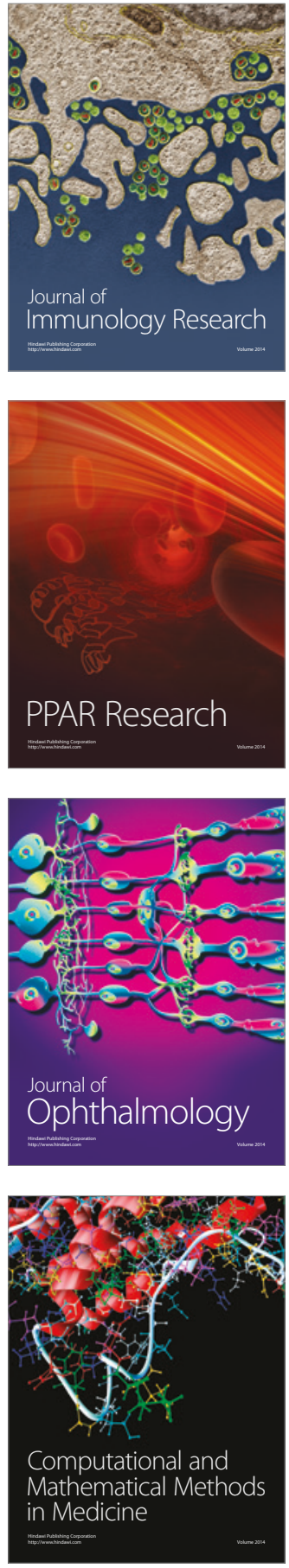

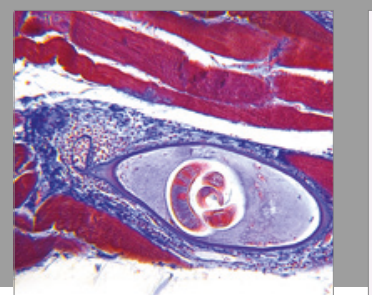

Gastroenterology Research and Practice
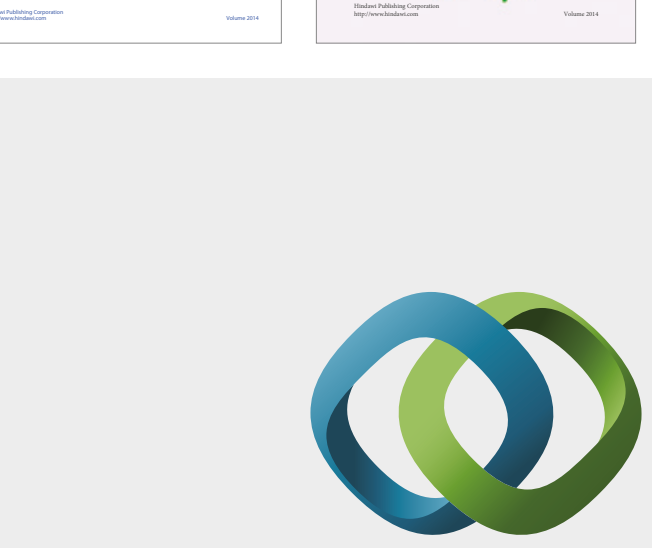

\section{Hindawi}

Submit your manuscripts at

https://www.hindawi.com
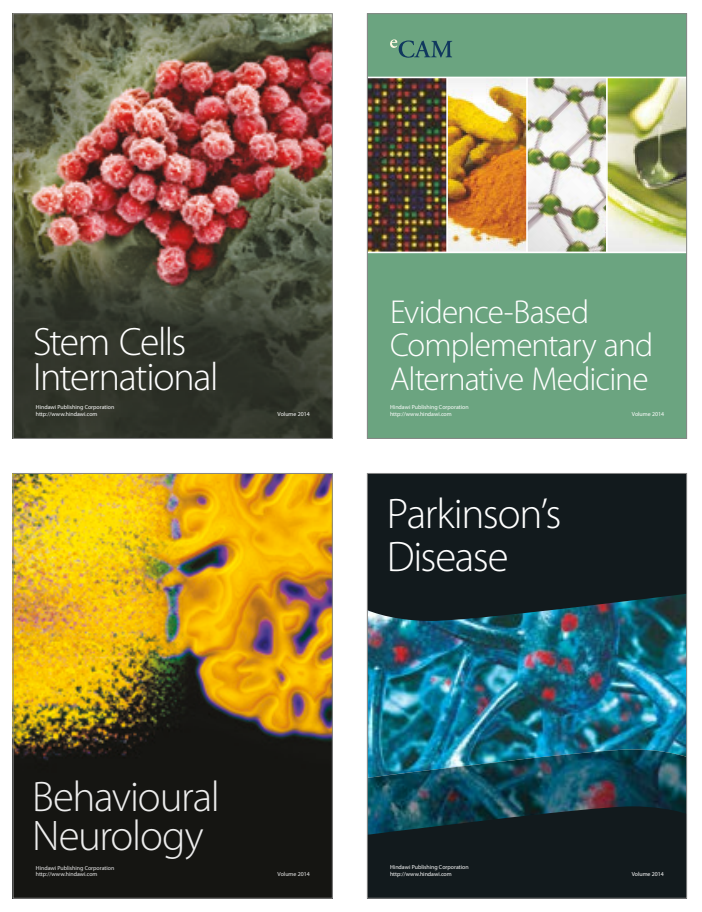
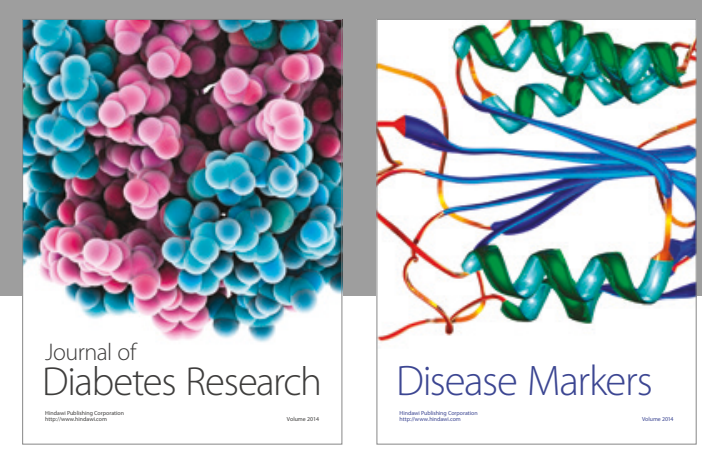

Disease Markers
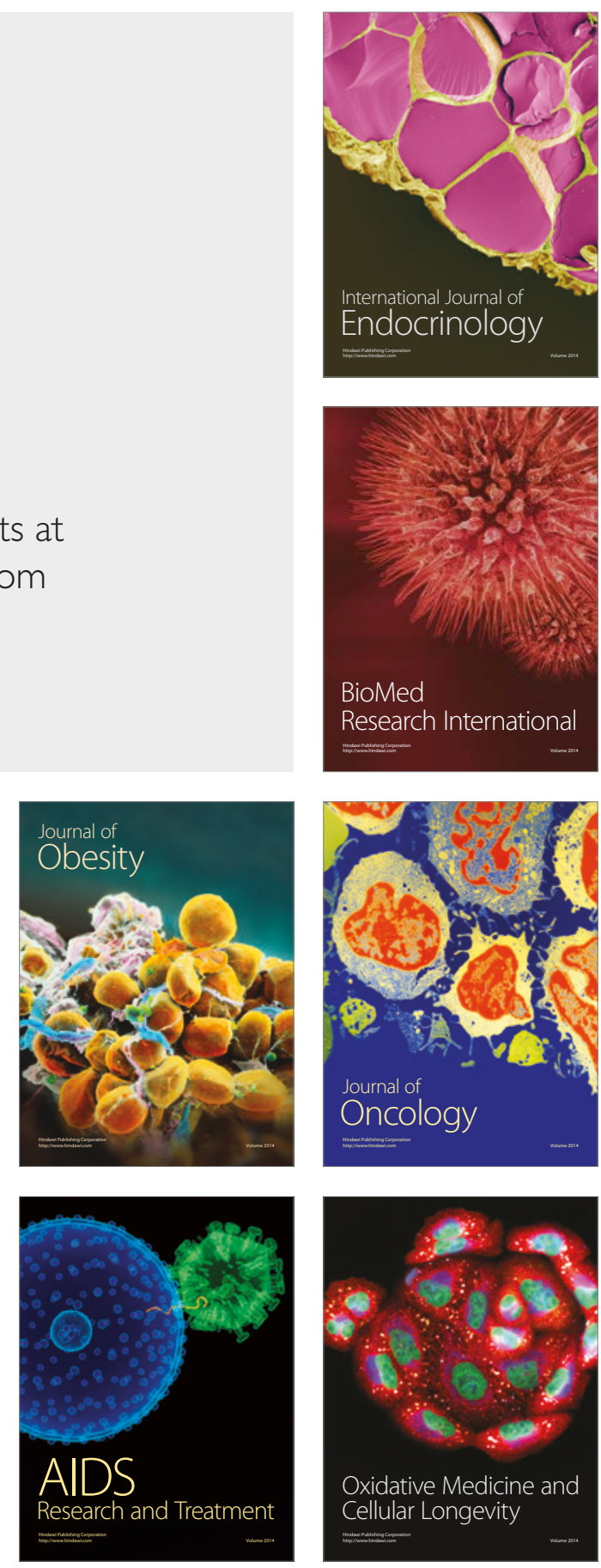